\title{
Avoidance of Double Taxation Based on OECD Agreements: Analyze of the Albanian-Italian model
}

\author{
Phd candidate Blendi Himçi \\ University "Aleksander Xhuvani” Faculty of Economic Departament of Law \\ Email:blendih@yahoo.com
}

Doi:10.5901/mjss.2014.v5n7p218

\begin{abstract}
Albania is already an indivisible part of the integration process in the European Union and in other international organizations, process which requires the implementation of the international agreements on the avoidance of the double taxation. The origin of the double taxation is in the conflict between the residence principle and source principle. It can be avoided only through the signature of international agreements, which based on the dispositions created by the parties, avoid the double taxation by appointing the state which has the right to tax certain incomes of certain subject, or share this right between the two states, for relief of the subject from the double taxation. There are different techniques or methods in avoiding the double taxation, but our country has generally used the credit method. It is important to be mentioned that based on the Albanian model of the tax agreements signed up to now, their dispositions are closer to the OECD and United Nations model. In general, avoidance of double taxation is accompanied by urge of foreign investments, growth of the market competition and better quality and lower costs of the goods offered. The present study will evidence the advantages accomplished through signature of these agreements aiming at the removal of double taxation on the same incomes, towards the economic agents and the performance by the later of different economic, entrepreneurial activities towards international markets.
\end{abstract}

Keywords: double taxation, agreement, income, business, commerce, avoidance.

\section{Theoretical Meaning of Double Taxation}

Double taxation occurs when under the provisions of the tax authorities of the same rank, for the same period of time, is charged with the same tax or taxes of the same type, the same tax subject or tax object ${ }^{1}$.

The issue of double or multiple taxes arises when connected factors provide competitive tax power to two or more states for the same income. The term "double taxation" is often confused with "over taxation " and " cumulative "tax due to conflict in tax rights. Over taxation rights, are observed in those cases when the same taxpayers, for the same period of time, pay two or more taxes of the same type to political-territorial units of different ranks. A case of over tax occurs when the income tax is paid to local and also central authorities ${ }^{2}$. We are in front cumulative tax when the same taxpayer for the same period of time and from the same tax source pays different kinds of taxes. Cumulative tax occurs when taxpayers, from their incomes, pay personal income tax of the employees, taxes on buildings as well as from those incomes pay the tax on trade and customs to purchase imported products, these taxes are included in the purchase price of the product. Cumulative taxation is found in all tax systems.

\section{Methods Avoiding the Double Taxation}

\subsection{Exemption method}

Income or capital that are taxable in the source state, are exempted from tax in the state of residence, but this can be taken into account in determining the tax rate applicable to the remainder of the income and capital of the taxpayers. In cases of progressive tax rates is to exclude the effect of income or capital in question with the average rate of tax on total income or capital. When the remaining of the income is negative, the effect of the exemption with progression may be to cut losses that otherwise would be available, e.g. to be carried to the next year. In practice though countries often exclude

\footnotetext{
${ }^{1}$ Rohatzi,Roy,Basic International Taxation., Kluwer Law International,2002

2 Klaus Vogel on double taxation conventions,1991,Kluwer Law and Taxation Publishers, Deventer, The Netherlands
} 
positive foreign incomes, foreign losses in many cases are deductible 3 .

\subsection{Credit method}

Income or capital that are taxable in the source state, are subject to tax in the state of residence, but the tax burden in the state of source is credited against the tax load that is assigned in the state of residence of these incomes or capital ${ }^{4}$.

However, there can be facilities by giving the exclusive rights to introduce income tax, in question, to the source state or to the state of residence (where the first case is an implementation of the exclusion method). If the double taxation is not removed by one of the two methods mentioned above, the competent authorities may, in some cases, resolve the problem through mutual agreement procedure, or other methods such as arbitration. Mitigation from the international economic double taxation is generally granted unilaterally instead of the tax agreement. This mitigation usually takes the form of an exemption or indirect credit, or, in the case of transfer pricing, the corresponding specification 5 .

\section{The Need to Conclude a Tax Agreement}

International conventions against double taxation are an instrument of international policy, necessary to avoid the phenomena that the same assumption is subject to tax twice in two different states.

In fact, conventions regulate the relationship between tax entities operating in countries that are signatories to the Convention and that are connected to the same thing. This tool aims to avoid income tax in the place where it is produced and also in the residence place of the person who has produced it. To mitigate the effects of double taxation on income, an action that a country can take is to conclude an agreement for the avoidance of double taxation on a bilateral basis with other countries.

Conventions or agreements on the elimination of double taxation with respect to taxes on income and on capital, which in practice are often named double taxation agreements or simply tax agreements, create a legal base for all individuals or companies that become subject to tax in the two states between which the agreement is concluded. These agreements aim, as well as the avoidance of tax evasion by individuals or companies that have operations in the two states between which the agreement is concluded. Under these conditions, these agreements have an important role in the complexities of factors, which guarantee, favor and promote international trade and economic relations.

The need to conclude tax agreements increases especially with the continued growth of international companies (multinational), which operate simultaneously in several countries (about 60 percent of world trade is performed by multinationals). Having activity in some states, multinationals are under the tax jurisdiction of the some countries, which complicates and hinders the collection of taxes in each state. In such cases, double taxation may happen, but also tax evasion which makes necessary the conclusion of tax treaties.

\section{Income Subject to an Agreement ${ }^{6}$}

Tax Agreements eliminate double taxation by determining which of the Contracting States has the right to tax certain income or capital, or to share the tax right between the two countries but without burdening the taxpayer with double income tax. Income subject to tax agreements are:

\subsection{International transport}

The right to tax the profits from the operations of ships and airplanes in the international traffic remains with the Contracting State in which the place of effective management of the entrepreneurship is situated (headquarters). So in the case of international transport, the tax right is given to only one state (where there is effective management of the company, where it is resident) independently from the existence of a permanent establishment in the other state. So based on this paragraph foreign companies such Olympic Air, Turkish Airlines, Alitalia, for their profits from the operations

\footnotetext{
${ }^{3}$ Article $23 A$ of OECD model

${ }^{4}$ Sen,P.\&Turnovsky,S.J(1990) Investment tax credit in an open economy, Journal of Public Economics,42,pp 277-299. Refering to the book of Genta Bungo "Science on finance and financial law "pg. 238

${ }^{5}$ Credit and exception in tax agreements in the cases of the characterization of the changeable income

${ }^{6}$ M.Pires "Measures designed to avoid or eliminate double taxation, Tax Power, Volume 2 pg.131-134.
} 
of their airplanes in international transport activity in Albania are respectively taxed in Greece, Turkey, Italy, independently if they have a branch (permanent office in Albania). While Albanian Airlines, Albatros, Belle Air (which are managed in Albania Albanian - resident companies) are taxed in Albania, although they may have branches in Italy, Greece and Turkey.

Difficulties in interpretation often arise from activities connected with international transport. So, ticket sales also for other companies, advertising activities related to air transport, transit services, passenger transportation to the airport, and transport of goods, are considered ancillary that are part of or directly related to international transport and are treated according to the provisions of the above-mentioned paragraph.

\subsection{Related entrepreneurships}

Tax Administration of one of the contracting states has the right to change the accounts of an entrepreneurship for the effects of the tax calculation for the transactions with related parties where the value of these transactions does not match the value of the market. The re-characterization methods are based on the principle of "arm" s length and are methods of compared prices between independent parties, methods plus costs, methods resale price minus. It should be taken under consideration that corrections can be connected to all modes of transport for the supply of goods and services, but also in the interest payment royalties paid to the copyright, the right to use patents etc. Re-characterization can create an economic double taxation so the same income in the hands of two persons is taxed twice; once in place where the regulation took place and once in the place where this income was taxed in accordance with the value of the transaction before the regulation. The agreement obliges the other state to do the corresponding regulation or as it called the secondary regulation.

\subsection{Dividends}

Dividend is the distribution of profits from joint-stock companies of any firm to persons who are the shareholders (individuals or legal entities). Right to dividend tax does not belong to any contracting country exclusively. Therefore neither country of residence nor the country where such dividends are created, where the company is resident makes the distribution of dividends. The right in this case is shared between the two contracting countries. Dividends that are paid by the resident company of a Contracting State to a resident of the other Contracting State shall be taxable in the other state therefore in the country where so beneficiary of the dividends is resident. When a non-resident company (Greek) distributes dividends they are related to profits arising in Albania. These dividends cannot be liable to tax unless they are paid to a resident person Albanian or when Greek company has a permanent establishment and paid dividends are attributable to that permanent establishment.

\subsection{Interests}

Tax on interest is done in the country where there is the resident, the beneficiary of the interest, but this right is not exclusive. Interests are considered with a source in Albania, when paid by an Albanian company, however, if a foreign company, for example Italian, pays interest for a loan used for business of a permanent establishment that the Italian company has in Albania and the interests are created by this permanent establishment then the source of interests is the country where the permanent establishment resides, thus in this case Albania.

The definition of the term "interest with dividend" is valid for the purposes of the agreement to avoid differences that exist between domestic legislations in the characterization of different incomes as dividends. What's important is the distinguishing of the dividend (participating in risk of business with the right to participate in company profits), the requirements of debt, from interests (which has a fixed level of income previously agreed, regardless of the outcome of the company and this distinction is important not only for the treatment of tax change that may have dividend with interests, but especially for the fact that interest is deductible expense for tax purposes while dividends are not.

\subsection{Royalties or incomes from the use of copyright}

Incomes or royalties from copyrights, that are incomes from the use of the right of "intellectual property" or industrial intangible assets such as licenses, patents, etc., the right to tax the royalties, is the right of the country where the beneficiary is the resident, but this right is not exclusive. 


\subsection{Capital earnings}

Gains from the sale of real estate covering also the earnings of the sale of business assets are taxed in the country of source (where the immovable properties exists). Earnings from the sale of movable property belonging to the business property of a permanent establishment which an enterprise of a contracting state has in the other state or of movable property that an individual of one state has in another state, shall be taxed in the state where the permanent establishment exists.

\subsection{Independent personal services}

Incomes from independent personal activities of lawyers, engineers, teachers, doctors, dentists, architects are taxed in their country of residence unless the individual has a fixed base in the source country. In such a case, the income attributable to the fixed base is taxed in the source country.

\subsection{Dependent personal services}

Employment income is taxed in the source country, where employment is exercised. The right to tax is given to the country of residence, but only if the following three conditions are met: the presence of less than 183 days, the employer is not a resident of the source country; the payment is not made by an employer's permanent establishment in the source country.

\subsection{Awards of the company executives}

The right of the taxation belongs exclusively to country of residence of the company.

\subsection{Artists and sportsmen}

The right of the taxation is of the source state. It applies not only directly to the individual, but also to legal persons controlled by artist (rent a star company).

\section{Agreement between the Republic of Albania and the Government of the Italian Republic for the Removal of Double Taxation with Respect to Taxes on Income and Capital and the Prevention of Fiscal Evasion}

This agreement was signed on 12/12/1994 in two copies, in Albanian and English, but in case of doubt, the English text shall be used. The aim of this agreement is to establish a clear legal basis for the tax treatment of individuals or legal entities Italian or Albanian who have business activities or other income that fall under the jurisdiction of the tax legislation of the two states.

The Government of the Republic of Albania and the Government of the Italian Republic desiring to conclude a Convention for the avoidance of double taxation with respect to taxes on income and on capital and prevention of tax evasion have agreed as follows.

This convention consists of 30 articles dividing these into seven parts (chapters according to the OECD model).

\subsection{The purpose of the Convention}

The purpose of this convention is determined exactly in Article 1 and Article 2. This Convention is applied to persons who are resident in one or two Contracting States. Some taxes that will be covered by this convention in the case of Albania according Article 2 are:

1. Personal income tax

2. Tax on profits

3. Taxes on small businesses when deducted at source

In the case of Italy according Article 2 are:

1. Personal income tax

2. Tax on income of legal persons when deducted at source 


\subsection{Income and capital tax}

Having activity in both states or being a resident of one state that provides income in another state, the individual or legal entity may be exacerbated by being taxed on the same income twice, or can create prerequisites for tax evasion or for tax evasion.

This agreement gives the right to tax certain income of only one state or dividing this right between the two countries, but without double burdening.

Some of the main issues covered by this agreement are:

- Treatment on income and on capital

- Treatment of income from marine transport in inland waters and air transport where the right to tax is given full to the state of residence that has the airline or shipping company that carries on the business of international transportation

- Avoidance of double taxation on income from dividends, the taxation will be done by dividing the tax right between the two countries, royalties, intellectual property - copyrights, patents, and such income will be taxed in the country of residence of the taxpayers, but this right is not exclusive.

- Tax right for income tax from the sale of real estate belongs to the country in which such real estate, regardless of the residence of the taxpayer.

- Treatment of income from independent personal services (professional services).

- Treatment of income from employment, reward of directors of companies, artists and sportsmen income, income from pensions, etc.

- The right to tax capital (including property tax), when this capital consists of real estate it is the right of the contracting state in which such property exists.

\section{Methods for Elimination of Double Taxation}

It is agreed that double taxation in this Agreement shall be avoided by the method prescribed in Article 24 of this agreement.

\subsection{For the case of Italy}

If a resident of Italy owns items of income which are taxable in Albania, Italy, on tax assignment of its income defined in Article 2 of this Convention, may include in the basis of taxation such items called elements of income, except in special cases where the provisions of this Convention predict otherwise. In this case, Italy shall deduct from taxes calculated in the paid tax on income from Albania, but the amount of deductions should not exceed the percentage of the Italian tax feature of revenue elements predicted in the proposal in which he contributes to the formation of total revenue.

\subsection{For the case of Albania}

If a resident of Albania derives income which, in accordance with the provisions of this Convention, may be taxed in Italy, Albania concludes that by imposing taxes on income drawn from the called resident (inhabitant), an amount equals to total income paid in Italy. However, such discounts cannot pass the quota set by Italy, on calculated income before deductions that are consistent to the income tax in Italy. If, in accordance with the legislation of a contracting state, the tax on business profits to which this Convention applies are eliminated or reduced for a limited period of time, such taxes deemed to be paid in full at the end of the application of paragraphs 2 and 3 of this article.

\section{Non-Discrimination}

Agreement also has specific provisions which consist of the elimination of tax discrimination. This provision cannot be construed as obligation of a contracting state to guarantee the residents of the other contracting state, any exemption, reliefs and reductions that guarantees its residents because of their condition or their family responsibilities. This means that the effects of this Convention shall extend only to persons who are residents of one or both of the contracting -party states?

${ }^{7}$ Article 24 of the OECD convention model 


\section{Information Exchange}

For the successful fulfillment of the objectives of this tax agreement is of a very important matter the exchange of information. On bases of which countries exchange information and cooperate to prevent tax evasion by entities that has operations in the two countries. The provisions of paragraph 1 of this Article may in no case be interpreting in a matter that it does not impose on contracting states the obligation:

a. To carry out administrative measures in divergence with the laws or practices of the other contracting state;

b. To supply information which is not obtainable under the laws within the administrative practice of that or of the other contracting state?

c. To provide information that will reveal secrets, commercial business, industrial, professional secret or trade process, or information the disclosure of which would be contrary to public order.

\section{Conclusions}

1. International agreements on the elimination of double taxation help in improving relations between countries and the creation of better conditions for the movement of goods and services, people and capital to stimulate the activity of individuals and businesses. Completion of tax agreements with the European Union countries helps accelerate the integration process of Albania.

2. Fiscal sustainability and suitable climate for investment serve as catalyst for attracting foreign capital. Fiscal sustainability performance is an indicator that promotes foreign direct investments. In this framework, the avoidance of double taxation affects foreign investors not to withdraw from the drive to bring their capital in our country.

3. Double taxation arises as a result of overlap or conflict of residence principle of the taxpayer and the source of income principle.

4. There are several methods that exist for the elimination of double taxation. Republic of Albania uses ordinary credit method. Our state allows deduction of paid tax in another state up to $10 \%$ of income earned in a foreign country. If the amount paid there has been less than $10 \%$, it is totally compensated, but if it has been greater than $10 \%$, it will be compensated up to this extent. The difference between the rate paid and the $10 \%$ it is paid by the individual in the form of double taxation.

5. For combating tax evasion, an important contribution is also given by the mutual exchange of information related to business transactions between the two countries.

6. Ratification of the international tax agreements implies certain behavior on the part of economic agents. These agreements are for the avoidance of double taxation: businesses (individuals) resident who aim to expand their activities beyond the state; businesses (individuals) non-residents who aspire to invest in our country. An important role in the conclusion of agreements is played by the state, as the economy of our country is in transition and aspires to me member of European Union.

7. The large number of agreements signed by our country and globalization make it more urgent the adoption of multilateral agreements on the elimination of double taxation as the right solution for the administration of these agreements.

8. Holding of evidence about foreign investors who invest in our country, but also of the Albanian taxpayers, who earn income overseas by the General Directorate of Taxation, can give sufficient information to assess the costs and benefits of such decision.

\section{References}

Bruins, Einaudi, Seligman and Stamp, Report on double taxation, the League of Nations, 1923;

M. Pires, "Measures designed to avoid or eliminate double taxation", Kluwer , 1989 ;

S. Cnossen, "What kind of company tax", Bulletin for International Fiscal Documentation, no. 1, 3.1993;

"Lending and dealing with the tax exemption in cases of characterization of income that varies", British Tax Journal, no. 3, 2,121,996;

Law No. 8371, dated 07.09.1998 "On Concluding Agreement and treaties ";

Law No. 8438, dated 28.12.1998 "On income tax" as amended;

Minister of Finance instruction No. 24, dated 09.02.2008 "On tax procedures in the Republic of Albania";

Model of income tax and capital (OECD);

Bungo, Genta , "Science on finance and financial law " ILAR 2007; 